IIUM Journal of Educational Studies, 1:1 (2013) 98 - 149

Copyright (C) IIUM Press

\title{
Relationship between Religious Commitment and Career Decision Making Among International Islamic University Malaysia (IIUM) Students
}

\author{
Aisha Mohamed Rashad
}

\begin{abstract}
This study is an exploration of the relationship between religious commitment and career decision making among students at the International Islamic University Malaysia. The sample of this study consisted of two hundred and thirty students. The major hypotheses of the study were that (a) the degree of religious commitment among students in IIUM is high, (b) the students are highly confident in their career decisions; (c) there is a positive correlation between confidence in career decisions and religious commitment. The instruments used were Career Decision Scale (CDS) and Religious Commitment Inventory (RCI). The results found that students of IIUM have a high level of religious commitment and a moderate level of confidence in career decision-making. Multivariate Analysis of Variance showed a significant difference between local and International students with international students having more confidence in career decision-making. Using statistical analysis of correlation, results did not show any significant relationship between CDS and RCI as was predicted by the hypothesis. However, the results showed a significant, positive relationship between the 'career certainty' subscale and religious commitment. These findings have important implications for career counsellors, as they show the importance of religious commitment in career counseling.
\end{abstract}

\section{Introduction}

Making a career choice is something every individual has to make at one point in his or her life. As such, some individuals make the wrong choice only to realize later on that they could have made the right one if given proper guidance. Because of this, public policies on career guidance and counseling are receiving increased recognition and support in developed countries. These policies and services are designed to assist individuals in managing their careers, at any time during their lives, in order to make informed vocational and educational choices. Such guidance uses self-assessment and 
IIUM Journal of Educational Studies, 1:1 (2013) 98 - 149

Copyright (C) IIUM Press

information gathering, to ensure individuals' decisions are based upon proper knowledge of themselves and the labour market, thereby reducing failure.

Nevertheless, career decision-making has become a major dilemma for university students. Each year, a number of university students are changing their major during their studies. Research has found that after enrolling in college, about $50 \%$ of the students change their major at least once (Corkin, Arbona, Coleman \& Ramirez, 2008) and over 50\% of college freshmen in the United States seek professional advice in choosing a career (Hannah \& Robinson, as cited in Ki-Hak, 2005). Several studies are also being conducted to identify the factors that are influencing this career indecision. Although there is no one theory that has effectively explained the phenomenon of career indecisiveness, variables such as personality, locus of control and inadequacy of information have all been found to have an influence on the trend (Gaffner \& Hazler, 2002).

There are several theories that explore the process of career decision-making and one of them is the spiritual approach. Miller-Tiedeman's life career model proposes that an individual's spirit is an important factor that affects their lives and career. Their spiritual energy and motivation provide a direction for them in their lives and making their decisions (Sharf, 2004). However, there are only a limited number of empirical studies that have explored the relationship between spirituality and career decision-making process. Most of the current research in the area of spirituality, religion, and career development is focused mostly on understanding the degree to which spirituality and religiousness affect the way individuals handle careerspecific tasks (Duffy, 2006a). Hence, the identified problem is the lack of available research conducted in Muslim society regarding religious commitment and career decision-making. Therefore, this study is attempting to examine the relationship 
IIUM Journal of Educational Studies, 1:1 (2013) 98 - 149

Copyright (C) IIUM Press

between religious commitment and career decision-making among Muslim students. For this purpose this study has tried to understand the degree of religious commitment and confidence among students of International Islamic University Malaysia. This study has enquired to what extent the students are confident about their career decisions, and tried to determine the relationship between religious commitment and confidence about career decisions. It is assumed that the degree of religious commitment among students in IIUM is high and therefore they are highly confident in their career decisions. It has also been assumed that there is a positive correlation between confidence in career decisions and religious commitment.

In this study Confidence in career decision is defined as the degree of confidence one has in deciding on a career choice as measured by the Career Decision Scale (Osipow, Carney, Winer, Yanico, \& Koschier, 1987), while Religious commitment refers to a person's relationship with a certain religion, or faith as measured by Religious Commitment Inventory (Worthington, Wade, Hight, Ripley, McVullogh, Berry, 2003).

\section{THEORIES OF CAREER DEVELOPMENT}

The literature in career making has provided different theoretical models in career decision-making and these models have provided an overview of how individuals make career decisions. Career theories offer a framework within which client behaviour can be examined and use it to identify, understand, and respond to clients' career goals or problems (McDaniels \& Gysbers, 1992). However, before looking into these theories, one must understand what is meant by the term career and career development. Arthur, Hall, \& Lawrence (1993) defined career as the evolving sequence of a person's work experiences over time. The National Career Development Association defined it as "the time extended working out of a 
IIUM Journal of Educational Studies, 1:1 (2013) 98 - 149

Copyright (C) IIUM Press

purposeful life pattern through work undertaken by the person" (Reardon, Lenz, Sampson, \& Peterson, 2000: 6). According to these definitions, career is not just the vocation or job one chooses. It is a more complex term, which involves all the activities and positions in an individual's life throughout his lifetime of work.

The term career development as defined by the American Counseling Association is "the total constellation of psychological, sociological, educational, physical, economic, and chance factors that combine to influence the nature and significance of work in the total life span of any given individual” (Engels, 1994: 2). There are several theories explaining career development. Gelso and Fretz (2001) grouped them into four categories: trait oriented theories, social learning and cognitive theories, developmental theories, and person-in-environment theories.

Trait-factor theories have been the oldest theoretical approach to career development (Osipow \& Fitzgerald, 1996). These trait-oriented theories are rooted in Frank Parson's vocational counseling paradigm of matching individual traits with the requirements of occupations (Zunker, 2006). According to Parson, optimal career choices require three steps for individuals to take. They are knowledge of self, knowledge of work environments, and some methods of matching the characteristics of one's self to those of work (Arthur, et al, 1993). Hence, in trait and type theories, the basic postulation is that every individual has different traits and needs, and that the requirement of each occupational environment is different. Therefore, for an individual to make a good career choice, it is imperative that he or she must first understand himself or herself, then the working world, and then match both to find a good fit.

There are several trait and type theories. Some of them are trait and factor theory, work adjustment theory, person-environment-correspondence counseling, 
IIUM Journal of Educational Studies, 1:1 (2013) 98 - 149

Copyright (C) IIUM Press

Holland's typological theory, and Myers-Briggs type theory (Sharf, 2004; Zunker, 2006). In trait and factor theory, the major assumptions are that individual's and occupation's traits can be matched and that the closer the match, the more occupational success and satisfaction the individual will get (Seligman, 2004).

Similarly, work adjustment theory focuses on assessing an individual's needs and skills so that they can be matched with similar needs and skills required by the occupations (Sharf, 2004). This theory maintains that work is not only task oriented, but also includes human interaction with all its psychological aspects. According to this theory, both the individual and the work environment have to meet each other's requirements in order to establish a positive relationship (Zunker, 1998). According to this theory, job satisfaction is very crucial for work adjustment.

Another theory that is based on traits is Holland's typology theory. Developed by John Holland, this theory assumes that "people express themselves, their interests, and values through their work" (Sharf, 2004: 90). According to this theory, individuals are attracted to a given career because of their unique personalities (Zunker, 1998). Hence, Holland classified peoples' personalities and how they interact with environment into six different types. They are: Realistic, Investigative, Artistic, Social, Enterprising, and Conventional. A basic assumption of Holland's theory is that vocational satisfaction, stability, and achievement depend on the congruence between one's personality and the environment where he works (Arthur et al, 1993). This theory also predicts that individuals with matching occupations will be more satisfied and less likely to change environments than will individuals with mismatching occupations. Secondly, persons with mismatching occupations will be influenced by the environment in which they are working towards congruence. 
IIUM Journal of Educational Studies, 1:1 (2013) 98 - 149

Copyright (C) IIUM Press

Therefore, basically, all the trait and factor theories are built on the notion that each individual has a set of personalities and each occupation and work environment has its own requirements and characteristics. Hence, for an individual to be satisfied and fully function, these two have to be matched and be congruent.

On the other hand, social learning theory proposes that social conditioning, social position, and life events are important in influencing career choice. According to Krumboltz's social learning theory, the process of career development involves four factors which are genetic endowments and special abilities which include inherited qualities rather than learned skills that can set limits on an individual's career opportunities; environmental conditions and events which include factors that are outside the control of an individual; learning experiences in which the individuals learn through reactions to consequences or through direct observations; and task approach skills which include a set of skills the individual develops throughout his life (Zunker, 1998).

Krumboltz emphasizes that these experiences lead the individual to the ultimate career choice (Zunker, 2006). According to social learning theories, individuals come to a certain career decision after considering many variables (Osipow \& Fitzgerald, 1996). Self-efficacy is one of the major concepts in social learning theory and has been found to be related to career decision-making and career planning (Osipow \& Fitzgerald, 1996). Hence, social leaning theories are very important in understanding the career choices of individuals.

A similar approach to social learning theory is the relational approach to career development. This approach is concerned with the impact and influence of parents on their children's career development and career decision making. One of the pioneers of this approach is Anne Roe who suggested that the occupational selection of an 
IIUM Journal of Educational Studies, 1:1 (2013) 98 - 149

Copyright (C) IIUM Press

individual is based on the psychological needs that develop from the interaction between children and their parents (Sharf, 2004). According to Roe, there are three types of parents' attitudes towards their child which affects the child's career choice (Sharf, 2004). The first type is concentration on the child where parents are overprotective and over demanding. The second type is avoidance of the child where the child is rejected emotionally by being criticized and punished. The third type is acceptance of the child where parents encourage the child and there is a tension free environment between the parents and child. All these play an important role in deciding occupations for the child when they grow up.

The development theories have also been very instrumental in explaining the career development of an individual throughout his lifespan. One of the major proponents of this approach is Donald Super. His lifespan theory centres on the notion of self-concept. He believes that vocational self-concept develops through physical and mental growth, observations of work, identification with working adults' general environments, and general experiences. According to Super, vocational selfconcept is formed step by step throughout an individual's lifespan as they become more aware of the world of work and also through experience (Zunker, 2006). He emphasized the fact that clients have a better chance of making optimal decisions when they are most aware of the working world and themselves and this is very important for counselors to work on (Zunker, 2006).

Another developmental theory which is similar to Super's theory in which career choice happens in stages is put forth by Ginzberg, Ginsburg, Axelrad, and Herma which suggests that vocational choice is a process that happens in three stages during an individual's life. These are Fantasy, Tentative, and Realistic periods (Cited 
IIUM Journal of Educational Studies, 1:1 (2013) 98 - 149

Copyright (C) IIUM Press

in Osipow \& Fitzgerald, 1996). These periods are further divided into stages, which the individuals go through as they grow from childhood into being adults.

Overall, these approaches to career development theories give career counselors a broader picture of individual's career development process. Each individual is unique and hence, they may require different ways to help them with their career dilemma. As such, career counselors can work with each individual as a unique case and apply the approach that can best fit the individual.

\section{THEORIES RELATED TO RELIGION AND SPIRITUALITY}

The above mentioned theories are more concerned with how the individuals make their career and occupational choice. The following part is designed to discuss career decision-making theories, which are related to spirituality and religiosity.

The approach, which is known as Miller-Tiedeman's Lifecareer Foundation differs from other career theories because according to this perspective, an individual's spirit is an important factor that affects their lives and career. Their spiritual energy and motivation provide a direction for them in their lives and making their decisions (Sharf, 2004). A study by Huntly shows how Christianity helps clients understand their career decision-making process. In another study, Stolz-Loike applies Judaism in understanding career and career decision making (Cited in Sharf, 2004).

In their book, 'Soul Work', Bloch and Richmond proposed that spirituality and work are connected through seven principles. These principles are: change, balance, energy, community, calling, harmony and unity. Combined, these seven themes reflect a spiritual approach to career decision-making (Sharf, 2004). Bloch also argued that people who understand their work as spiritual also consider their 
IIUM Journal of Educational Studies, 1:1 (2013) 98 - 149

Copyright (C) IIUM Press

contribution to the world, avoid self-centeredness, and integrate their work lives with their personal lives (Duffy, 2007).

Hansen's Integrative Life Planning Approach is a holistic approach that encourages people to connect various life aspects by providing a framework for helping individuals understand and integrate work, family, and spirituality so that they could achieve a sense of wholeness and life satisfaction (Perrone, Webb, Wright, Jackson \& Ksiaza, 2006). Hansen (2001) emphasizes on integrating the mind, body, and spirit. He argues that broader kinds of self-knowledge (beyond interests, abilities, and values) and societal knowledge (beyond occupational and educational information) are critical to an expanded view of career, including multiple roles, identities, and critical life tasks in diverse cultures. According to Hansen (2001), spirituality embraces purpose, meaning, connectedness, and sense of community. It may or may not include religion. Career choices are spiritual in that they are expressions of one's gifts and talents. Spiritual questions individuals can ask are "What does work mean in my life?" and "What do I want in my life through my work?". When individuals integrate spirituality in choosing a career, they embrace and celebrate life journeys, regardless of the path followed or led down. It opens up attitudes of flexibility and openness to foster development, give way to opportunities for learning and growth, and celebrate and embrace change.

These theories suggest that spirituality and religiousness plays an important role in career development, including career decision making, job satisfaction, and work values of individuals.

\section{FACTORS AFFECTING CAREER DECISION-MAKING}

During the past decades, much research has been conducted in an attempt to provide an explanation for career decision-making difficulties among college students. As 
IIUM Journal of Educational Studies, 1:1 (2013) 98 - 149

Copyright (C) IIUM Press

such, several studies have been conducted to find out the major factors that contribute to career decision-making (Johnson, 2007; Thompson, 2001). The most common factors that are being studied include family, information about world of work, locus of control and personality (Gaffner \& Hazler, 2002). However, more recently, researchers have taken interest in studying the effects of religiosity or spirituality on the career development and work.

Gaffner and Hazler (2002) conducted a study to find the factors related to indecisiveness in college students. Their study tried to explore the relationship between a student's level of indecisiveness and lack of career readiness, lack of career information received, difficulty in decision-making, and four personality types. The sample consisted of 111 undergraduate students (56 women and 55 men) in their first or second year in a private Mid-western university. All of the participants were undecided about their major. The researchers used the Myers-Briggs Type Indicator, Career Factors Inventory, and the Career Decisions Difficulties Questionnaire. The results found a correlation between the level of indecisiveness and the level of career readiness, the amount of occupational information received, and the amount of difficulty in decision-making.

In her research, Etta (1999) examined the relationship and predictability of personal, social, and family variables on the career decision making of college students. A total of one hundred students completed an Assessment of career Decision Making and a demographic questionnaire. The variables tested were age, gender, ethnicity, socioeconomic status, family structure, college grade point average, parent's occupation, and employment status. The author found a significant relationship between ethnicity and socioeconomic status and students' progression in 
IIUM Journal of Educational Studies, 1:1 (2013) 98 - 149

Copyright (C) IIUM Press

selecting a college major. However, no significant relationship was found for age, gender family structure and grade point average.

Johnson (2007) conducted a research to determine what relationship exists between deciding career, motivational level, locus of control, and attributional style. The sample size of this study consisted of 95 ninth grade students. Some of the demographic variables taken into account for this study were student socioeconomic status, involvement in special programming at school (i. e. Exceptional Education, or Advanced Placement), parental education level, and parental occupation. The researcher used Career Decision Scale (CDS), Children's Attributional Style Questionnaire-Revised (CASQ-R), Children's Nowicki-Strickland Internal External Locus of Control Scale (CNISE), and the Five Item Polarized Motivation Scale to collect the data. Using ANOVA and Mann Whitney test, as well as a series of simple linear regression analyses, the results showed only predictive relationships among the variables existed between career certainty and motivation, career indecision and attributional style, and locus of control and attributional style.

In another study, Ferguson (2007) also studied career decision and motivation. However, his study was focused on finding out whether there existed any relationships between career decision and the motivation to persist and career indecision and the lack of motivation to persist. The Career Decision Scale and the Achievement Motivation Profile assessments were administered to 105 students at a comprehensive community college. The results showed that there is a statistical relationship between career decision and motivation to persist. This study indicates that it is very important for students to have a clear career goal and make career decisions so that they have the motivation to continue their studies. 
IIUM Journal of Educational Studies, 1:1 (2013) 98 - 149

Copyright (C) IIUM Press

Career self-efficacy is also one of the factors researched in the field. Researchers, Mei and colleagues explored the factors influencing high school students' career aspirations. More specifically, they explored the relationship among learning experience, gender, career self-efficacy, outcome expectation, vocational interests, and career aspiration. 141 high school students from a Midwest suburban public school participated in the study. Instruments used by the researchers were a demographic questionnaire which included participants' paid work experiences, questions about family activities related to career awareness and exploration and questions related to school experiences, particularly focusing on career guidance; SelfDirected Search; and a measure of outcome expectation that was developed by the research team. The results of a structural equation modeling analysis supported the mediating role of career self-efficacy in the career decision-making process (Mei, Wei, \& Newmeyer, 2008).

\section{RELIGIOUS COMMITMENT IN CAREER DEVELOPMENT}

Before we discuss the relationship between carrier decision making and religious commitment it might be useful to examine some empirical research conducted on career decision-making. Over the past decade, there has been an interest in the role of spirituality and religion with respect to both physical and mental health. Although spirituality and religiousness are considered by some researches as the same (Rashid, 2004), others distinguish between the two. While spirituality generally refers to an individual's relationship with a higher power or powers, religiousness refers to a person's relationship with a certain religion, church, or faith community (Miller \& Thoresen, 2003). Since both concepts are interrelated, they will be interchangeable in this study. As such, several studies have been conducted to explore the phenomena of religiosity and spirituality. 
IIUM Journal of Educational Studies, 1:1 (2013) 98 - 149

Copyright (C) IIUM Press

In a research conducted among two hundred and thirty-five undergraduates (ages 18-25) from three universities, researchers attempted to assess outcomes associated with a religious/spiritual orientation toward life. For their study, the researchers used the Rohrbaugh-Jessor Religiosity Scale to measure religiosity, Allport Spirituality Scale to measure spirituality and Rosenberg Self-Esteem Scale to measure self-esteem. The data revealed that high religiosity is associated with higher self esteem, has more assets for healthy growth, and that those who scored high on religiosity and spirituality were least likely to be involved in such antisocial behaviors such as stealing, getting into trouble with the police, and damaging property (Knox, Langehough, Walters \& Rowley, 1998).

In a similar study, using 12,992 high school seniors, Trusty and Watts (1999) investigated bivariate relationships of high school seniors' religious perceptions and behaviour to several school-related, career-related, and leisure variables; and the mediating effects of parental involvement in predicting academic attitudes and drug use from religious perceptions and behaviour. For the purpose of their study, the authors used factor analyses to develop several variables (scales) for the study: The Religious Perceptions/Behavior scale that assessed the importance of religious activity, perceptions of religiousness, and attendance at religious services; The Life/ Career Outlook scale assessed perceptions of the future regarding job, family, friends, and general well-being; The Academic Attitudes scale which quantified the perceived importance of school, grades, and future educational achievement; The Drug Use scale that indicated drug use among friends and respondents' use of cigarettes, alcohol, and marijuana; and The Attendance Problems scale which indicated frequencies of school absences, tardiness, and skipped classes. Through correlations, the results revealed that those who perceived religion to be important in their lives and 
IIUM Journal of Educational Studies, 1:1 (2013) 98 - 149

Copyright (C) IIUM Press

participated in religious services seemed to also exhibit positive attitudes and behaviour regarding school, career, and leisure. Scores on the Religious Perceptions/ Behavior scale had the strongest relationships with (a) Drug Use scale scores (negative correlation), (b) volunteer work, (c) Academic Attitudes scale scores, and (d) Parental Involvement scale scores. However, there were weak negative relationships of Religious Perceptions/Behavior scale scores to Delinquency scale scores and to School Attendance Problems scale scores. Overall, the study found positive perceptions of religion and frequent attendance at religious activities were related to the following for high school seniors: (a) positive parental involvement, (b) positive perceptions of the future, (c) positive attitudes toward academics, (d) less frequent drug use, (e) less delinquent behaviour, (f) fewer school attendance problems, (g) more time spent on homework, (h) more frequent volunteer work, (i) recognition for good grades, and (j) more time spent on extracurricular activities. Based on this, the authors suggest that for prevention or remediation of problems for adolescents, counselors and educators should assess religious perceptions and behaviors and, if appropriate, address them.

In his study, Brown (2008) investigated the relationship between spirituality and anxiety and depression. One hundred and twenty two university students completed the Religious Problem-Solving Scale, the Spiritual Well-Being Scale, Beck Anxiety Inventory and the Beck Depression Inventory-II. Results yielded an inverse relationship between the spirituality and mental health assessments. More specifically, spirituality subscale measuring existential well-being was reported to have significant relationships with both mental health measures. On the other hand, no significant relationship was found between anxiety, depression and religious coping style. The author concluded that individuals reporting higher levels of 
IIUM Journal of Educational Studies, 1:1 (2013) 98 - 149

Copyright (C) IIUM Press

existential well-being also have lower levels of symptoms of anxiety and depression.

Such findings were also found in studies conducted in Malaysia. A study conducted in the Malaysian context investigated the relationship between religiosity and psychological well-being. The variables investigated were four aspects of religiosity- intrinsic orientation, extrinsic orientation- personal, extrinsic orientationsocial and religious behaviors, on the one hand, and three aspects of psychological well-being- anxiety, depression on the other hand. Two hundred and fifty students of three different races from four universities, including International Islamic University Malaysia participated in the study. The results showed a positive relationship between religiosity and psychological well-being. It was also found that female students had higher scores in religious behavioural dimension than male students, but no difference was found on the other three dimensions. The results also showed that Muslims had higher scores in religious behaviors, intrinsic orientation and extrinsic-personal orientation and lower scores in extrinsic-social orientation than others (Rashid, 2004).

In another research, which was conducted at the International Islamic University Malaysia, assessed the magnitude of, and gender differences in spiritual well-being of undergraduate university students (Syed Sohail Imam, 2009). With a sample size of 278 participants $(19.4 \%$ Males, mean age $=21.69$ years, $S D=1.68 ; 79.9 \%$ females, Mean age $=21.55, \mathrm{SD}=1.57)$, the study attempted to measure spiritual well-being, religious well-being, and existential well-being using the Spiritual Well-being Scale. Using a one sample t-test, it was found that the participants obtained significantly higher than the theoretical average on measures of overall spiritual well-being. Furthermore, an independent sample t-test analysis revealed significant gender differences in overall spiritual well-being and religious well-being with females scoring higher on both measures. However, in the case of existential well-being, 
IIUM Journal of Educational Studies, 1:1 (2013) 98 - 149

Copyright (C) IIUM Press

gender difference was marginally significant. Overall, the study found that students at the International Islamic University Malaysia have high levels of spiritual and religious well being.

Similarly, another study was also conducted at the International Islamic University Malaysia exploring religiosity (Houtouin, 2005). The purpose of the study was to examine how collective activities, cultural differences, English proficiency and religiosity affected social integration. The sample consisted of 350 students from both local and international students. Using questionnaires to measure all the variables, an interesting finding of the study was that local students reported higher religiosity than international students, but there was significant relationship between religiosity and social integration only among international students, and not among local students.

However, contrary results have also been found for the relationship between spirituality and well-being. In a study conducted with 262 university students, an attempt to examine the proposition that religiosity and spirituality are inversely associated with personal distress was done by Schafer (1997). The results showed mixed findings with no significant relationship between the spirituality/religiosity variables of Christian rebirth, dependence upon a larger power, belief in life after death, attendance at religious services, frequency of prayer, and current religious preferences and personal distress. On the contrary, a higher importance of religion in respondents' lives was associated with higher personal distress. However, a clear sense of meaning and direction was strongly associated with lower personal distress. The author gives some plausible explanation to the findings that perhaps placing high importance on religion resulted in internal guilt and anxiety about measuring up to divine expectations or in a sense of conflict with the surrounding secular world, both of which might in turn lead to high personal distress. 
IIUM Journal of Educational Studies, 1:1 (2013) 98 - 149

Copyright (C) IIUM Press

Like mental and physical health, spirituality and religious commitment plays an important role in individuals' career development and work. However, there are a limited number of researches been conducted regarding this issue and career development professionals refrain from bringing spirituality and religiosity into their work (Moshe, 2003). Nevertheless, there have emerged some studies that support the role of spirituality in individual's career development.

A phenomenological study conducted by Royce-Davis and Stewart (2000) attempted to understand the interaction between spirituality and career development among college students. Ten undergraduate students with diverse backgrounds in major year in school, and family and religion were chosen to participate in the study. Through open-ended questions, and follow up over a course of 12 months, the researchers found that spiritual struggles and spiritual growth have a significant impact on the participants' career development.

In another qualitative study, the relationship between religion, spirituality, and career development were explored using semi-structured interviews (Constantine, et al, 2006). Using a sample of 12 African American undergraduate students in a large, predominantly white, private university, the researchers conducted the study through interviews based on previous literature. Through the interviews, the researchers identified 6 domains: degree of identification, as religious or spiritual; parents' influence on religious beliefs; role of religion and spirituality in participants' career development; challenges in dealing with academic and career-related issues; religious and spiritual strategies to deal with academic and career-related challenges; and indicators of success in future career or occupation. In relation to the role of religion and spirituality in participants' career development, participants revealed that they believed God had a unique plan for their life through their career choice and that they 
IIUM Journal of Educational Studies, 1:1 (2013) 98 - 149

Copyright (C) IIUM Press

believed it was important to help or serve others through their work. Moreover, the study also found that religion and spirituality served as a critical shield against the challenges participants face as they work towards their career goal.

Similar studies have also been conducted to examine the impact of spirituality on career decision making. A quantitative study conducted by Duffy (2006a), with a sample size of 133 undergraduate students, also found similar results for the relationship between religion and career. The purpose of the study was to examine the relationship between religious support, social support, career exploration, and career decision self efficacy. Using questionnaires to measure God support, social support, religious community support, and CDSE, the results found significant correlations between one's level of social support and religious support, with CDSE but not career exploration.

A similar study was conducted by Duffy \& Blustein (2005) which examined the relationship between spirituality, religiousness, and career adaptability using a sample of one hundred and forty four undergraduate students. The authors hypothesized that higher levels of religiousness and spirituality would predict higher levels of career adaptability as measured by Career Decision Self Efficacy and Career Choice Commitment. The findings of the research partially supported the hypothesis. The authors concluded that individuals with high spirituality and religiosity tend to be more confident in their ability to make career decision.

Apart from studies on the career development of university students, research has also been conducted in other aspects of career as well. Collins (2008) conducted a study with 240 African American women and men. The purpose of the study was to examine the role of spirituality as a moderating factor between career barriers and career outcome expectations. The instruments used in the study were Career Barriers 
IIUM Journal of Educational Studies, 1:1 (2013) 98 - 149

Copyright (C) IIUM Press

Inventory-Revised (CBI-R), Outcome Expectations, and the Spiritual Involvement and Beliefs Scale. The career barriers studied were sex discrimination, racial discrimination, inadequate preparation, decision making difficulties, job market restraints, difficulties with networking. The results found that career barriers were not significantly related to outcome expectations and that spirituality did not serve as a facilitative factor between the two variables.

Studies were also done on career transition and spirituality. An exploratory study conducted by Akcali (2000) explored the relationship between spirituality and career transition process in middle-aged women's lives. In depth interviews were conducted with a sample of 20 women who were in or went through a transition process. The results of the study indicate ways in which spirituality impacts career transition process through reflection. In particular, it seemed to have an impact on the participants' lives at the time they engaged in re-thinking of who they were, through which kind of work they could reach a sense of harmony, and the meaning of their lives. The study also found that earlier religious education has an impact on the participants' current ethics and morals.

Furthermore, research has also been conducted to examine whether spirituality and religiousness influence work and work place. For example, a qualitative psycho biographical study which investigated whether there is evidence that spirituality does actually influence work behaviour among 16 participants (age 40 - 50) found that spirituality clearly influences work behaviour (Lips-Wiersma, 2002). In addition to that, in his research, Browne (2001) examined the relationship between religious orientation, religious commitment and work values amongst a sample of 401 undergraduate students. The participants were from a religious institution (the historically black religious college) and a non-religious institution (the predominantly 
IIUM Journal of Educational Studies, 1:1 (2013) 98 - 149

Copyright (C) IIUM Press

white university). The results found significant correlations between religious measures and several work values. More specifically, intrinsic religiosity and religious commitment were related to the work value of altruism while extrinsic religiosity and religious commitment was found to be related to the work value economic returns.

In a study that explored the relationship of spirituality to work and family roles and life satisfaction, Perrone and colleagues found that spirituality impacted the participants' work, marriage, parenting, and life satisfaction in many ways. The research was conducted among 99 college students using six instruments: Life satisfaction, spiritual well-being, marital satisfaction, parental satisfaction, work satisfaction and open ended questions. Quantitative analysis using multiple regression indicated that existential well-being and marital satisfaction contributed positively to life satisfaction. However, in the open-ended questions, participants indicated that their spiritual beliefs had little or no impact on their career development (Perrone, Webb, Wright, Jackson \& Ksiaza, 2006).

Boyce (2005) conducted a study among 312 participants (201 recruited through web-based and 109 recruited through Baptist church congregation) to investigate the role of religious support in reducing work family conflict. Using structural equation modeling to analyze the relationship between the multiple variable used, the results revealed mixed support for the relationship between religious support and stressors. Contrary to the researcher's expectation, it was found that higher levels of perceived spiritual support were associated with higher levels of family stress. In providing possible explanation for this result, the researcher suggests that it may be because when individuals face stressful situations, they seek help and support from God and their faith to help them cope with the situation. 
IIUM Journal of Educational Studies, 1:1 (2013) 98 - 149

Copyright (C) IIUM Press

A review of the theories and past literature suggests that spirituality and religious commitment plays a role in an individuals' life. Whether it is psychological well being or work satisfaction or work ethics, the role of spirituality and religious commitment cannot be undermined. Although there is no vast research done on spirituality and religious commitment, the limited research conducted on the subject gives some evidence that these factors play an important role in an individual's career development process and career decision making process. Hence, the present study was designed to assess the role of religious commitment in career decision-making.

\section{RESEARCH METHODOLOGY}

This study used a survey design to examine the relationship between religious commitment and career decision making. For the purpose of this study, questionnaires were used to collect data. The survey was conducted among 235 students who study in four different faculties of International Islamic University, Malaysia. These faculties were selected because they have the highest number of students. The demographic profile of the participants is presented in Table 3.1. As for the distribution of participants among the specializations, 30.6\% are in Laws $(n=72)$, $33.2 \%$ are in Economics ( $\mathrm{n}=78$ ), $22.1 \%$ are in IRKHS (Islamic Revealed Knowledge and Human Sciences) $(\mathrm{n}=52)$, and 11. 9\% are in Education $(\mathrm{n}=28)$.

\section{Table 3.1}

Distribution of respondents according to demographic variables

\begin{tabular}{cll}
\hline Demographic variables & $\mathrm{n}$ & $\%$ \\
\hline Respondent's origin & & \\
International & 69 & 29.4 \\
Local & 166 & 70.6
\end{tabular}

Age groups

17-20 years

21-25 years
16

191
81.3 
IIUM Journal of Educational Studies, 1:1 (2013) 98 - 149

Copyright (C) IIUM Press

26-31 years

32- and above

Gender

Male

Female

Years in faculty

First year

second year

third year

fourth year

Specialization

Law

Economics

IRK \& Human Sciences

Education

Major declared

Yes

No

Religion

\section{Islam}

25

3

60

175

25.5

74.5

33

80

14

34

$86 \quad 36.6$

$31 \quad 12.9$

72

30.6

78

33.2

22.1

$33 \quad 11.9$

197

83.8

35

14.9

235

100

The questionnaires were used in its original English version. The instruments that were used are Career Decision Scale (CDS) and Religious Commitment Inventory (RCI). The CDS consists of two scales: the Certainty Scale, which measures one's certainty of educational and occupational choice, and the Indecision scale, which measures the antecedents of educational and occupational indecision The Certainty Scale consists of the first two items of the instrument, and the sum of these first two items is the certainty score. Items 3 through 18 are the Indecision Scale, and the sum of the Indecision Scale items is the indecision score. A high score on the Indecision Scale indicates indecision regarding a career choice. Items 1 to 18 are all self-rated responses, and responses are made from a 4-point Likert scale, with a one indicating the item has low similarity to the respondent and a four indicating the item has high 
IIUM Journal of Educational Studies, 1:1 (2013) 98 - 149

Copyright (C) IIUM Press

similarity to the respondent. Item 19 is an open-ended question in which respondents can expand on or clarify prior items. Test-retest reliability for the Indecision Scale has consistently been reported to be above 0.80 .

RCI contains 10 statements which are rated on a 5 point likert scale ranging from $1=$ Not at all true of me, and 5 being "totally true of me". The instrument was designed to measure an individual's motivational and behavioural commitment to religious values. In a study of religious commitment among only Christian students, Worthington et al (2003) reported moderately high internal consistency reliability (Cronbach's alpha. 88).

Psychometric properties were obtained for the two scales used in the study. For internal consistency reliability, Cronbach's alpha was used (see Table 3.1). Results show that the mean score for career decision in this sample was $m=42.65$ (SD $=9.498)$ and $m=37.13(S D=7.27)$ for religious commitment. The scales were found to be acceptably reliable ( $\alpha=.881$ and $\alpha=.878$ respectively).

Table 3.2

Means, Standard Deviations and Cronbach Alpha Coefficients of Measures

\begin{tabular}{lllll}
\hline Measurements & $\mathrm{N}$ & $\mathrm{M}$ & $\mathrm{SD}$ & Alpha
\end{tabular}

\begin{tabular}{lllll}
\hline CDS & 18 & 4265 & 9.498 & .881 \\
RCI & 10 & 37.13 & 7.271 & .878
\end{tabular}

To analyze the data, the researcher employed several statistical procedures. First, descriptive statistics were used to answer the first six hypotheses. A frequency descriptive analysis of the sample was also conducted to find out participants' responses towards the items in the scales. Secondly, Multivariate Analysis of 
IIUM Journal of Educational Studies, 1:1 (2013) 98 - 149

Copyright (C) IIUM Press

Variance, Analysis of Variance and Independent Sample t-test was conducted to find the difference between selected variables with regards to the instruments.

Table 3.3

Statistical Method Employed

\begin{tabular}{llll}
\hline No. & Research Question & Data & Statistical Method \\
\hline 1 & $\begin{array}{l}\text { What is the degree of religious } \\
\text { commitment among students in } \\
\text { IIUM? }\end{array}$ & $\begin{array}{l}\text { Religious } \\
\text { Commitment } \\
\text { Inventory }\end{array}$ & $\begin{array}{l}\text { Descriptive statistics } \\
\text { and Frequency } \\
\text { Distribution }\end{array}$ \\
2 & $\begin{array}{l}\text { To what extent are the students } \\
\text { confident about their career } \\
\text { decisions? }\end{array}$ & $\begin{array}{l}\text { Career Decision } \\
\text { Scale }\end{array}$ & $\begin{array}{l}\text { Descriptive statistics } \\
\text { and Frequency } \\
\text { Distribution }\end{array}$ \\
$\begin{array}{l}\text { Is there any difference among } \\
\text { demographic variables in CDS } \\
\text { and RCI? }\end{array}$ & $\begin{array}{l}\text { Religious } \\
\text { Commitment } \\
\text { Inventory } \\
\text { Career Decision }\end{array}$ & $\begin{array}{l}\text { MANOVA, } \\
\text { ANOVA, T-Test }\end{array}$ \\
$\begin{array}{l}\text { What is the relationship between } \\
\text { religious commitment and } \\
\text { confidence about career } \\
\text { decisions? }\end{array}$ & RCI and CDS & Correlation \\
\end{tabular}

The current study also employed correlation to test the hypothesis. This design was chosen because the researcher attempted to find out the relationship religious commitment as independent variable and career decision-making as dependent variable among the participants. Additionally, it will help to identify the association between the variables in terms of direction and strength.

\section{RESULTS}

\section{Religious Commitment}

The first hypothesis was that the degree of religious commitment among students in

IIUM is high. Descriptive statistics were used to assess the respondents' level of 
IIUM Journal of Educational Studies, 1:1 (2013) 98 - 149

Copyright (C) IIUM Press

religious commitment as measured by Religious Commitment Inventory (RCI). The results showed that the mean for RCI for IIUM students is 28.43 with a minimum value of 12 and a maximum value of 40 . This shows that the level of religious commitment among the respondents is high. Thus, the first hypothesis is supported. Crosstabulations were also conducted to further assess the responses for each item within the four specializations. The results are shown in Table 4.1, 4.2, and 4.3. The mean and standard deviation is reported in Table 4.4.

Table 4.1

Students' response to religious commitment (religious practices)

\begin{tabular}{|c|c|c|c|}
\hline Item & Specialization & Like me & Not like me \\
\hline \multirow[t]{9}{*}{$\begin{array}{l}\text { I often read books and magazines about my } \\
\text { faith. }\end{array}$} & Law & $\begin{array}{c}13 \\
23.2 \%\end{array}$ & $\begin{array}{c}43 \\
76.8 \%\end{array}$ \\
\hline & \multirow[t]{2}{*}{ Econ } & 27 & 51 \\
\hline & & $34.6 \%$ & $65.4 \%$ \\
\hline & \multirow[t]{2}{*}{ IRKHS } & 20 & 31 \\
\hline & & $39.2 \%$ & $60.8 \%$ \\
\hline & \multirow[t]{2}{*}{ Edu } & 7 & 12 \\
\hline & & $36.8 \%$ & $63.2 \%$ \\
\hline & \multirow[t]{2}{*}{ Total } & 67 & 137 \\
\hline & & $32.8 \%$ & $67.2 \%$ \\
\hline \multirow{10}{*}{$\begin{array}{l}\text { I spend time trying to grow in understanding of } \\
\text { my faith. }\end{array}$} & \multirow[t]{2}{*}{ Law } & 24 & 32 \\
\hline & & $42.9 \%$ & $57.1 \%$ \\
\hline & \multirow[t]{2}{*}{ Econ } & 51 & 27 \\
\hline & & $65.4 \%$ & $34.6 \%$ \\
\hline & \multirow[t]{2}{*}{ IRKHS } & 33 & 18 \\
\hline & & $64.7 \%$ & $35.3 \%$ \\
\hline & \multirow[t]{2}{*}{ Edu } & 8 & 11 \\
\hline & & $42.1 \%$ & $57.9 \%$ \\
\hline & \multirow[t]{2}{*}{ Total } & 116 & 88 \\
\hline & & $56.9 \%$ & $43.1 \%$ \\
\hline \multirow{10}{*}{$\begin{array}{l}\text { It is important to me to spend periods of time in } \\
\text { private religious thought and reflection. }\end{array}$} & \multirow[t]{2}{*}{ Law } & 36 & 20 \\
\hline & & $64.3 \%$ & $35.7 \%$ \\
\hline & \multirow[t]{2}{*}{ Econ } & 57 & 21 \\
\hline & & $73.1 \%$ & $26.9 \%$ \\
\hline & \multirow[t]{2}{*}{ IRKHS } & 27 & 24 \\
\hline & & $52.9 \%$ & $47.1 \%$ \\
\hline & \multirow[t]{2}{*}{ Edu } & 11 & 8 \\
\hline & & $57.9 \%$ & $42.1 \%$ \\
\hline & \multirow[t]{2}{*}{ Total } & 131 & 73 \\
\hline & & $64.2 \%$ & $35.8 \%$ \\
\hline
\end{tabular}


IIUM Journal of Educational Studies, 1:1 (2013) 98 - 149

Copyright (C) IIUM Press

The items in table 4.1 are related to students' engagement in religious practices and the importance they give to growth in religious knowledge. The results show that the majority of students in the entire specializations do not read books about their faith (67.2\%). However, it also shows that the majority of students in all the specializations reported spending time in religious thoughts and reflection (64.2\%). As for spending time in growth in religion, the results show mixed findings with students in Economics (65.4\%) and IRKHS (64.7\%) scoring high, while only 42.9\% students in Law and $42.1 \%$ in Education agreeing with the statement. However, the difference is not much and it can be inferred that students in all the specializations do spend time in religious practices.

Table 4.2

Students' response to religious commitment (religious contribution)

\begin{tabular}{llcc}
\hline Item & Specialization & Like me & $\begin{array}{c}\text { Not like } \\
\text { me }\end{array}$ \\
\hline & & & \\
$\begin{array}{l}\text { I make financial contributions to my religious } \\
\text { organization. }\end{array}$ & Law & 17 & 39 \\
& & $30.4 \%$ & $69.6 \%$ \\
& Econ & 24 & 54 \\
& IRKHS & $30.8 \%$ & $69.2 \%$ \\
& & 12 & 39 \\
& Edu & $23.5 \%$ & $76.5 \%$ \\
& & 5 & 14 \\
& Total & $26.3 \%$ & $73.7 \%$ \\
I keep well informed about my local religious & Law & 58 & 146 \\
group and have some influence in its & & $28.4 \%$ & $71.6 \%$ \\
decisions. & & & \\
& Econ & 23 & 33 \\
& & $41.1 \%$ & $58.9 \%$ \\
& IRKHS & 39 & 39 \\
& & $50.0 \%$ & $50.0 \%$ \\
& Edu & 19 & 32 \\
& & $37.3 \%$ & $62.7 \%$ \\
& Total & 8 & 11 \\
& & $42.1 \%$ & $57.9 \%$ \\
& & 89 & 115 \\
& & $43.6 \%$ & $56.4 \%$ \\
& & &
\end{tabular}


IIUM Journal of Educational Studies, 1:1 (2013) 98 - 149

Copyright (C) IIUM Press

Table 4.2 shows some items that relate to students participation in religious activities. The results show that the majority of students in all the specializations scored negatively with the statements (71.6\% and 56.4\%). These results indicate that the respondents are not very active in participating in religious activities and groups.

Table 4.3

Students' response to religious commitment (religious belief)

\begin{tabular}{|c|c|c|c|}
\hline Item & Specialization & Like me & $\begin{array}{c}\text { Not like } \\
\text { me }\end{array}$ \\
\hline \multirow{10}{*}{$\begin{array}{l}\text { Religion is especially important to me } \\
\text { because it answers many questions about } \\
\text { the meaning of life }\end{array}$} & \multirow[t]{2}{*}{ Law } & 43 & 13 \\
\hline & & $76.8 \%$ & $23.2 \%$ \\
\hline & \multirow[t]{2}{*}{ Econ } & 69 & 9 \\
\hline & & $88.5 \%$ & $11.5 \%$ \\
\hline & \multirow[t]{2}{*}{ IRKHS } & 46 & 5 \\
\hline & & $90.2 \%$ & $9.8 \%$ \\
\hline & \multirow[t]{2}{*}{ Edu } & 14 & 5 \\
\hline & & $73.7 \%$ & $26.3 \%$ \\
\hline & \multirow[t]{2}{*}{ Total } & 172 & 32 \\
\hline & & $84.3 \%$ & $15.7 \%$ \\
\hline \multirow{10}{*}{$\begin{array}{l}\text { My religious beliefs lie behind my whole } \\
\text { approach to life }\end{array}$} & \multirow[t]{2}{*}{ Law } & 38 & 18 \\
\hline & & $67.9 \%$ & $32.1 \%$ \\
\hline & \multirow[t]{2}{*}{ Econ } & 61 & 17 \\
\hline & & $78.2 \%$ & $21.8 \%$ \\
\hline & \multirow[t]{2}{*}{ IRKHS } & 31 & 20 \\
\hline & & $60.8 \%$ & $39.2 \%$ \\
\hline & \multirow[t]{2}{*}{ Edu } & 13 & 6 \\
\hline & & $68.4 \%$ & $31.6 \%$ \\
\hline & \multirow[t]{2}{*}{ Total } & 143 & 61 \\
\hline & & $70.1 \%$ & $29.9 \%$ \\
\hline \multirow{10}{*}{$\begin{array}{l}\text { Religious beliefs influence all my } \\
\text { dealings in life. }\end{array}$} & \multirow[t]{2}{*}{ Law } & 37 & 19 \\
\hline & & $66.1 \%$ & $33.9 \%$ \\
\hline & \multirow[t]{2}{*}{ Econ } & 69 & 9 \\
\hline & & $88.5 \%$ & $11.5 \%$ \\
\hline & \multirow[t]{2}{*}{ IRKHS } & 34 & 17 \\
\hline & & $66.7 \%$ & $33.3 \%$ \\
\hline & \multirow[t]{2}{*}{ Edu } & 14 & 5 \\
\hline & & $73.7 \%$ & $26.3 \%$ \\
\hline & \multirow[t]{2}{*}{ Total } & 154 & 50 \\
\hline & & $75.5 \%$ & $24.5 \%$ \\
\hline
\end{tabular}


IIUM Journal of Educational Studies, 1:1 (2013) 98 - 149

Copyright (C) IIUM Press

The results in Table 4.3 show that the majority of the respondents acknowledge that religion is very important in their life. More precisely, Economics students scored very high on all the items (88.5\%, 78.2\%, and $88.5 \%)$ followed by IRKHS (90.2\%, 60.8\%, and 66.7\%). However, an interesting finding is that students in IRKHS did not score very high in all the items as compared to other specializations even though students in IRKHS are expected to have higher level of religious commitment as they are specializing in and taking more subjects of religion.

Table 4.4

Overall Mean and Standard Deviation of respondents towards RCI

\begin{tabular}{llllll}
\hline Variables & $\underline{\mathrm{N}}$ & Minimum & Maximum & Mean & Std.Deviation \\
\hline RCI & 235 & 12.0 & 40.0 & 28.44 & 5.87 \\
\hline
\end{tabular}

\section{Career Decision Making}

The second hypothesis was that IIUM students are highly confident in their career decisions. Mean and frequency tables were run to test the hypothesis. The results showed that the mean for CDS among students were 40.4 with a minimum value of 12 and a maximum value of 72 , indicating that the students are confident in their career decisions. Crosstabultaion tables were also run to find the frequency and percentages for the two subscales within the four Specializations. The results are shown in Table 4.6.

Table 4.5

Overall Means and Standard Deviation of Respondents towards CDS

\begin{tabular}{llllll}
\hline Variables & $\underline{\mathbf{N}}$ & Minimum & Maximum & Mean & Std.Deviation \\
\hline CDS & 235 & 18 & 72 & 40.4 & 10.24 \\
\hline
\end{tabular}


IIUM Journal of Educational Studies, 1:1 (2013) 98 - 149

Copyright (C) IIUM Press

\begin{tabular}{lccccc}
\hline Certainty & 235 & 2 & 8 & 6.0 & 1.3 \\
Indecision & 235 & 16 & 64 & 36.54 & 9.77 \\
\hline
\end{tabular}

\section{Career Certainty}

Students' specializations were crosstabulated against the career certainty subscale items. Students' specializations examined were Law, Economics, IRKHS and Education. The results show that the percentage of students who responded positively is higher than those who had responded negatively. This is across all the Specializations and no major difference is seen. Specifically, more than $75 \%$ of Law students reported that they were comfortable with their chosen career field. A comparable majority (78.2\%) of Economic students, (62.7\%) of IRKHS, and 73.7\% of Education students also were found to be certain about their selected career choice.

Table 4.6

Students' response to Career Certainty subscale

\begin{tabular}{llcc}
\hline \multicolumn{1}{c}{ Item } & Specialization & Like me & Not like me \\
\hline $\begin{array}{l}\text { I have decided on a career and feel } \\
\text { comfortable with it. I also know how to go } \\
\text { about implementing my choice. }\end{array}$ & Law & 43 & 14 \\
& Econ & $75.4 \%$ & $24.6 \%$ \\
& & 61 & 17 \\
& IRKHS & $78.2 \%$ & $21.8 \%$ \\
& Edu & 32 & 19 \\
& & $62.7 \%$ & $37.3 \%$ \\
& Total & 14 & 5 \\
& & $73.7 \%$ & $26.3 \%$ \\
$\begin{array}{l}\text { I have decided on a major and feel } \\
\text { comfortable with it. I also know how to go }\end{array}$ & Law & 150 & 55 \\
about implementing my choice. & & $73.2 \%$ & $26.8 \%$ \\
& Econ & 41 & 16 \\
& & $71.9 \%$ & $28.1 \%$ \\
& IRKHS & 65 & 13 \\
& & $83.3 \%$ & $16.7 \%$ \\
& Edu & 43 & 8 \\
& & $84.3 \%$ & $15.7 \%$ \\
& Total & 18 & 1 \\
& & $94.7 \%$ & $5.3 \%$ \\
\hline
\end{tabular}


IIUM Journal of Educational Studies, 1:1 (2013) 98 - 149

Copyright (C) IIUM Press

In the case of comfort level of the chosen major, $94.7 \%$ of Education students reported being comfortable with their chosen major. Furthermore, a comparable majority of IRKHS students (84.3\%), Economic students (83.3\%), and Law students (71.9\%) were found to have similar response. This indicates that students in all the Specializations are certain about their career choice and major choice.

\section{Career Indecision}

Table 4.7 shows the frequency of students' responses to some of the items in the indecision subscale across Specializations. For the purpose of clarification, items that are similar are grouped together. Table 4.8 shows students' responses towards their need for knowledge about themselves. The results showed that majority of the responses are positive. This indicates that students are in need of more guidance in knowing about themselves and their interests. With respect to Specialization and individual items, $63.2 \%$ of Law students agreed that they still needed skills to improve their career choice. Similarly 52.6\% of Economics students also had a similar need. However, 52.6\% of Education students and 51.0\% of IRKHS disagreed with the statement, indicating that both Education students and IRKHS students are already equipped with the skills they need for their career choice.

Table 4.7

Students' response to Career Indecision subscale (knowledge about self)

\begin{tabular}{|c|c|c|c|}
\hline Item & Specialization & Like me & Not like me \\
\hline If I had the skills or opportunity, I know I would be a & Law & $\begin{array}{r}36 \\
63.2 \%\end{array}$ & $\begin{array}{r}21 \\
36.8 \%\end{array}$ \\
\hline $\begin{array}{l}\text { But this choice is really not possible for me. I haven't } \\
\text { given much consideration to any other alternatives, }\end{array}$ & Econ & $\begin{array}{r}41 \\
52.6 \%\end{array}$ & $\begin{array}{r}37 \\
47.4 \%\end{array}$ \\
\hline
\end{tabular}


IIUM Journal of Educational Studies, 1:1 (2013) 98 - 149

Copyright (C) IIUM Press

\begin{tabular}{|c|c|c|c|}
\hline \multirow[t]{5}{*}{ however. } & IRKHS & $\begin{array}{r}25 \\
49.0 \%\end{array}$ & $\begin{array}{r}26 \\
51.0 \%\end{array}$ \\
\hline & Edu & 9 & 10 \\
\hline & & $47.4 \%$ & $52.6 \%$ \\
\hline & Total & 111 & 94 \\
\hline & & $54.1 \%$ & $45.9 \%$ \\
\hline \multirow{10}{*}{$\begin{array}{l}\text { Having to make a career decision bothers me. I'd like } \\
\text { to make a decision quickly and get it over with. I } \\
\text { wish I could take a test that would tell me what kind } \\
\text { of career I should pursue. }\end{array}$} & Law & 28 & 29 \\
\hline & & $49.1 \%$ & $50.9 \%$ \\
\hline & Econ & 43 & 35 \\
\hline & & $55.1 \%$ & $44.9 \%$ \\
\hline & IRKHS & 28 & 23 \\
\hline & & $54.9 \%$ & $45.1 \%$ \\
\hline & Edu & 12 & 7 \\
\hline & & $63.2 \%$ & $36.8 \%$ \\
\hline & Total & 111 & 94 \\
\hline & & $54.1 \%$ & $45.9 \%$ \\
\hline \multirow{10}{*}{$\begin{array}{l}\text { I don't know what my interests are. A few things } \\
\text { "turn me on" but I'm not certain that they are related } \\
\text { in any way to my career possibilities. }\end{array}$} & Law & 35 & 22 \\
\hline & & $61.4 \%$ & $38.6 \%$ \\
\hline & Econ & 41 & 37 \\
\hline & & $52.6 \%$ & $47.4 \%$ \\
\hline & IRKHS & 32 & 19 \\
\hline & & $62.7 \%$ & $37.3 \%$ \\
\hline & Edu & 11 & 8 \\
\hline & & $57.9 \%$ & $42.1 \%$ \\
\hline & Total & 119 & 86 \\
\hline & & $58.0 \%$ & $42.0 \%$ \\
\hline
\end{tabular}

In the case of need for more information about careers and world of work, the results follow the same pattern as need for knowledge about self. The results in Table 4.8 show that the majority of students in all the specializations showed positive response in their need for information about occupations. However, an interesting finding is that students in Law seem to have scored the highest (50.9\%, 77.2\%) compared to students in IRKHS (49.0\% and 70.6\%). Another interesting finding is that even though students in Education are already attached to schools and are school teachers, they have also scored high on some of the items (68.4\% and 73.7\%).

Table 4.8

Students' response to Career Indecision subscale (need for information)

\begin{tabular}{|c|c|c|c|}
\hline Item & Specialization & Like me & Not like me \\
\hline I know what I'd like to major in, but I don't know & Law & 29 & 28 \\
\hline what careers it can lead to that would satisfy me. & & $50.9 \%$ & $49.1 \%$ \\
\hline
\end{tabular}


IIUM Journal of Educational Studies, 1:1 (2013) 98 - 149

Copyright (C) IIUM Press

\begin{tabular}{|c|c|c|c|}
\hline & Econ & 35 & 43 \\
\hline & & $44.9 \%$ & $55.1 \%$ \\
\hline & IRKHS & 25 & 26 \\
\hline & & $49.0 \%$ & $51.0 \%$ \\
\hline & Edu & 10 & 9 \\
\hline & & $52.6 \%$ & $47.4 \%$ \\
\hline & Total & 99 & 106 \\
\hline & & $48.3 \%$ & $51.7 \%$ \\
\hline I think I know what to major in, but I feel I need & Law & 41 & 16 \\
\hline some additional support for it as a choice for myself. & & $71.9 \%$ & $28.1 \%$ \\
\hline & Econ & 53 & 25 \\
\hline & & $67.9 \%$ & $32.1 \%$ \\
\hline & IRKHS & 31 & 20 \\
\hline & & $60.8 \%$ & $39.2 \%$ \\
\hline & Edu & 14 & 5 \\
\hline & & $73.7 \%$ & $26.3 \%$ \\
\hline & Total & 139 & 66 \\
\hline & & $67.8 \%$ & $32.2 \%$ \\
\hline I need more information about what different & Law & 44 & 13 \\
\hline occupations are like before I can make a career & & $77.2 \%$ & $22.8 \%$ \\
\hline decision. & Econ & 47 & 31 \\
\hline & & $60.3 \%$ & $39.7 \%$ \\
\hline & IRKHS & 36 & 15 \\
\hline & & $70.6 \%$ & $29.4 \%$ \\
\hline & Edu & 13 & 6 \\
\hline & & $68.4 \%$ & $31.6 \%$ \\
\hline & Total & 140 & 65 \\
\hline & & $68.3 \%$ & $31.7 \%$ \\
\hline
\end{tabular}

Table 4.9 below shows student responses towards items that indicate their indecision in choosing careers. The results showed that in all the specializations, students responded negatively towards the items (62.9\%, 64.4\%, and 67.8\%). Only $25.5 \%$ of IRKHS students are uncertain about their careers. A comparable minority of 29.5\% of Economics students have similar results. However, there is a slight difference between both these two specializations and Education and Law (36.8\% and $40.4 \%$ respectively). This difference is seen in the other items as well.

Table 4.9

Students' response to Career Indecision subscale (feeling confused)

\begin{tabular}{|c|c|c|c|}
\hline Item & Specialization & Like me & Not like me \\
\hline \multirow{3}{*}{$\begin{array}{l}\text { I know I will have to go to work eventually, but none } \\
\text { of the careers I know about appeal to me. }\end{array}$} & Law & 24 & 33 \\
\hline & & $42.1 \%$ & $57.9 \%$ \\
\hline & Econ & 28 & 50 \\
\hline
\end{tabular}


IIUM Journal of Educational Studies, 1:1 (2013) 98 - 149

Copyright (C) IIUM Press

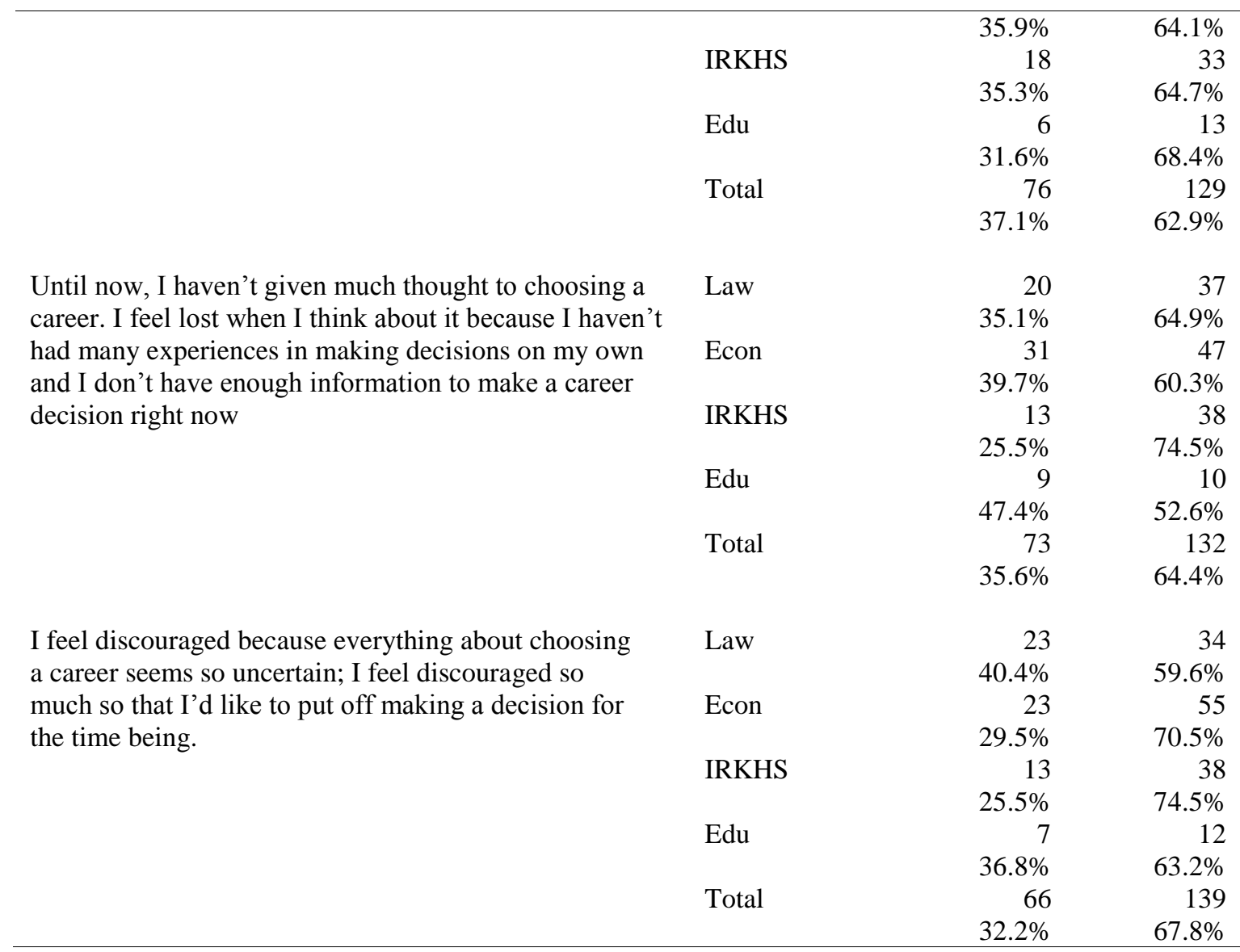

\section{Nationality And Specialization Differences Among Participants}

To determine whether there is any difference between the nationality of students, their specialization and their level of confidence in career decision-making and religious commitment, a factorial MANOVA was conducted consisting of two factors: nationality and specialization. The dependent variables tested in the MANOVA were scores on the CDS and RCI. The results are presented in Table 4.10

Table 4.10

Summary of Factorial MANOVA's scores on CDS and RCI

\begin{tabular}{llll}
\hline & Wilks' $\Delta$ & Approx. $\underline{P}$ & $P$ \\
\hline Nationality effects & .944 & 6.741 & .001 \\
Specialization & .970 & 1.164 & .324 \\
effects & & & \\
\hline
\end{tabular}


IIUM Journal of Educational Studies, 1:1 (2013) 98 - 149

Copyright (C) IIUM Press

$\begin{array}{llll}\text { Nationality and } & .979 & .805 & .566 \\ \text { Specialization } & & & \end{array}$

Result of the MANOVA on the score on CDS and RCI revealed that there was a significant multivariate effects of nationality (Wilkis' $\Delta=.944, \underline{\mathrm{F}}=6.741, p=.001$ ). The multivariate effect of specialization ( Wilkis' $\Delta=.970, \underline{\mathrm{F}}=1.164, p=.324$ ) was not significant. The multivariate interactive effects between nationality and specialization were not significant (Wilkis' $\Delta=.979, \underline{\mathrm{F}}=.805, p=.566$ ). Methodologically, given the presence of multivariate nationality and specialization, the application of Univariate analysis was in order. Hence, Univariate analysis was conducted to explore if there was a significant difference in participants' responses towards CDS and RCI according to nationality and specialization.

\section{Certainty subscale}

The results for Univariate F-test indicated that there is no significant difference between specialization and certainty subscale $\underline{\mathrm{F}}(3,227)=.677, p=0.567$. However, the test also indicated that there is a statistically significant difference between main effect of nationality and certainty subscale, $\underline{F}(1,227)=4.156, p=0.043$. The means and standard deviations of scores for certainty subscale are presented in Table 4.11.

Table 4.11

Mean scores for nationality and specialization for certainty subscale

\begin{tabular}{lcccccc}
\hline & & Law & Econ & IRKHS & Edu & Total \\
\hline \multirow{2}{*}{ International } & $\mathrm{M}$ & 3.2 & 3.166 & 3.2 & 3.3 & 3.2 \\
& $\mathrm{SD}$ & .59 & .86 & .67 & .62 & .74 \\
\hline
\end{tabular}


IIUM Journal of Educational Studies, 1:1 (2013) 98 - 149

Copyright (C) IIUM Press

\begin{tabular}{|c|c|c|c|c|c|c|}
\hline & $\mathrm{N}$ & 10 & 33 & 14 & 12 & 69 \\
\hline \multirow[t]{3}{*}{ Local } & $\mathrm{M}$ & 2.9 & 3.12 & 2.8 & 3.1 & 3.0 \\
\hline & SD & .67 & .68 & .53 & .62 & .64 \\
\hline & $\mathrm{N}$ & 62 & 45 & 38 & 21 & 166 \\
\hline \multirow[t]{2}{*}{ Total } & & 2.9 & 3.1 & 2.9 & 3.1 & \\
\hline & & 72 & 78 & 52 & 33 & \\
\hline
\end{tabular}

The results show the mean for international students $(\underline{M}=3.2)$ is higher than the mean for local $(\underline{M}=3.0)$. Thus scores on the certainty subscale for CDS are significantly and substantially associated with nationality. More precisely, international students scored higher than the local students on the certainty scale on CDS. However, there is no significant difference in the mean scores among the specializations of Law, Economics, IRKHS and Education ( $\underline{\mathrm{M}}=2.9, \underline{\mathrm{M}}=3.1, \underline{\mathrm{M}}=2.9$, $\underline{M}=3.1$ respectively).

\section{Indecision}

The $\underline{F}$ - test for the main effect of nationality was statistically very significant; $\underline{F}$ $(1,227)=12.469, M s=4.373, p=0.001$ (table). On the other hand, the F-test for the main effect of specialization was not significant, $\underline{\mathrm{F}}(3,227)=.805, p=.492$. The results are shown in Table 4.12.

Table 4.12

Univarite F-Test for Indecision subscale

Df $\quad$ Mean Square $\quad \underline{F} \quad$ Sig.


IIUM Journal of Educational Studies, 1:1 (2013) 98 - 149

Copyright (C) IIUM Press

\begin{tabular}{lcccc}
\hline Nationality & 1 & 4.373 & 12.469 & .001 \\
& 227 & .351 & & \\
Specialization & 3 & .282 & .805 & .492 \\
& 227 & .351 & & \\
\hline
\end{tabular}

The means and standard deviation of the scores on the indecision sub scale of the CDS are presented in Table 4.13.

Table 4.13

Mean scores for nationality and specialization for indecision

\begin{tabular}{lcccccc}
\hline & & Law & Econ & IRKHS & Edu & Total \\
\hline International & $\mathrm{M}$ & 2.3 & 2.0 & 1.9 & 1.9 & 2.03 \\
& $\mathrm{SD}$ & .52 & .75 & .512 & .519 & .64 \\
& $\mathrm{~N}$ & 10 & 33 & 14 & 12 & 69 \\
Local & $\mathrm{M}$ & 2.4 & 2.5 & 2.4 & 2.3 & 2.4 \\
& $\mathrm{SD}$ & .64 & .46 & .57 & .56 & .57 \\
& $\mathrm{~N}$ & 62 & 45 & 38 & 21 & 166 \\
& & 2.3 & 2.2 & 2.3 & 2.1 & \\
\hline Total & & 72 & 78 & 52 & 33 & \\
& & & & & & \\
\hline
\end{tabular}


IIUM Journal of Educational Studies, 1:1 (2013) 98 - 149

Copyright (C) IIUM Press

The result shows that the mean score for local students (2.4) is higher than the mean scores for international students (2.03). This shows that international students are more confident with regards to their career choice compared to local students. The results do not show any difference between the specializations.

\section{Religious Commitment}

The mean and standard deviations of the scores on the RCI are presented in Table 4.14. The F-test for the main effect of nationality was not significant; $\underline{F}(1,227)=$ $.335, p=0.563$. Similarly, the results showed that the main effect of specialization was also not significant, $\underline{\mathrm{F}}(3,227)=1.485, p=0.219$. The results are shown in the table below.

Table 4.14

Univariate F-test for Religious Commitment

\begin{tabular}{lcccc}
\hline & $d f$ & Mean Square & $\underline{\mathrm{F}}$ & Sig. \\
\hline Nationality & 1 & .154 & .335 & .563 \\
& 227 & .460 & & \\
Specialization & 3 & .682 & 1.485 & .219 \\
& 227 & .460 & & \\
& & & & \\
\hline
\end{tabular}

The result of the mean scores shows that the mean score for both local (3.6) and international students (3.6) is high with no difference between the groups. This indicates that the respondents have high levels of religious commitment regardless of 
IIUM Journal of Educational Studies, 1:1 (2013) 98 - 149

Copyright (C) IIUM Press

their nationality. Similarly, there is not much difference in the mean scores for the specialization of Law, Economics, IRKHS and Education $(\underline{\mathrm{M}}=3.6, \underline{\mathrm{M}}=3.7, \mathrm{M}=3.4$, $\underline{\mathrm{M}}=3.6$ respectively).

Table 4.15

Mean scores for Nationality and Specialization on RCI

\begin{tabular}{lllllll}
\hline & & Law & Econ & IRKHS & Edu & Total \\
\hline International & $\mathrm{M}$ & 3.6 & 3.6 & 3.2 & 3.8 & 3.6 \\
& $\mathrm{SD}$ & .42 & .52 & .44 & .517 & .51 \\
& $\mathrm{~N}$ & 10 & 33 & 14 & 12 & 69 \\
Local & $\mathrm{M}$ & 3.6 & 3.7 & 3.5 & 3.6 & 3.6 \\
& $\mathrm{SD}$ & .99 & .44 & .53 & .64 & .73 \\
& $\mathrm{~N}$ & 62 & 45 & 38 & 21 & 166 \\
& & & & & & \\
\hline Total & & 3.6 & 3.7 & 3.4 & 3.6 & \\
& & 72 & 78 & 52 & 33 &
\end{tabular}

\section{Grade Level Differences among Participants}

A one-way analysis of variance (ANOVA) was conducted to evaluate the differences in CDS overall score and its subscales and RCI between the different levels of study. The results show that respondents in the four levels of study did not differ in their reported RCI, $\underline{\mathrm{F}}(3,231)=0.349, p=.790$ and in the certainty subscale, $\underline{\mathrm{F}}(3,231)=$ 1.12, $p=0.342$. On the other hand, the results also showed that there is a significant difference among the four levels in both CDS overall score, $\underline{\mathrm{F}}(3,231)=3.178, p=$ 0.025; and also for indecision subscale, $\underline{F}(3,231)=2.954, p=0.03$. Tukey post-hoc comparisons of the four groups on the CDS indicate that the level 3 respondents $(\underline{\mathrm{M}}=$ 2.4, 95\% CI [2.24, 2.47]) gave significantly higher ratings than level four respondents on CDS ( $\underline{\mathrm{M}}=2.08,95 \%$ CI $[1.93,2.23]), p=.030$. Similarly, level 3 respondents $(\underline{\mathrm{M}}$ 
IIUM Journal of Educational Studies, 1:1 (2013) 98 - 149

Copyright (C) IIUM Press

$=2.3,95 \%$ CI $[2.27,2.5])$ also gave significantly higher rating than level four respondents on Indecision Scale ( $\underline{\mathrm{M}}=2.1,95 \%$ CI $[1.9,2.2]), p=0.042$. The results are shown in the Table below.

Table 4.16

Univariate Analysis of Variance test between student's level of education, and, RCI and CDS

\begin{tabular}{|c|c|c|c|c|c|c|}
\hline \multirow[t]{2}{*}{ variables } & & \multirow{2}{*}{$\begin{array}{l}\text { Sum of } \\
\text { Squares }\end{array}$} & \multicolumn{3}{|c|}{ Mean } & \multirow{2}{*}{ Sig. } \\
\hline & & & & & \multirow{4}{*}{3.178} & \\
\hline \multirow[t]{3}{*}{ CDS } & $\begin{array}{l}\text { Between } \\
\text { Groups }\end{array}$ & 3.00 & 3 & 1.001 & & \multirow[t]{3}{*}{.025} \\
\hline & Within Groups & 72.72 & 231 & .315 & & \\
\hline & Total & 75.70 & 234 & & & \\
\hline \multirow[t]{3}{*}{ Certainty } & $\begin{array}{l}\text { Between } \\
\text { Groups }\end{array}$ & 1.537 & 3 & .512 & \multirow[t]{3}{*}{1.120} & \multirow[t]{3}{*}{.342} \\
\hline & Within Groups & 105.650 & 231 & .457 & & \\
\hline & Total & 107.187 & 234 & & & \\
\hline \multirow[t]{3}{*}{ Indecision } & $\begin{array}{l}\text { Between } \\
\text { Groups }\end{array}$ & 3.230 & 3 & 1.077 & \multirow[t]{3}{*}{2.954} & \multirow[t]{3}{*}{.033} \\
\hline & Within Groups & 84.217 & 231 & .365 & & \\
\hline & Total & 87.447 & 234 & & & \\
\hline \multirow[t]{3}{*}{ RCI } & $\begin{array}{l}\text { Between } \\
\text { Groups }\end{array}$ & .482 & 3 & .161 & \multirow[t]{3}{*}{.349} & \multirow[t]{3}{*}{.790} \\
\hline & Within Groups & 106.468 & 231 & .461 & & \\
\hline & Total & 106.951 & 234 & & & \\
\hline
\end{tabular}

\section{Gender Differences among Participants}

The results of Independent Samples T-test to analyze the differences among females and males on both the scales showed that there is no significant difference between the males and females and the CDS overall score, $\underline{\mathrm{t}}(233)=-1.513, p=0.13$. However, there was a statistically significant difference between males and females on the 
IIUM Journal of Educational Studies, 1:1 (2013) 98 - 149

Copyright (C) IIUM Press

Certainty subscale, $\underline{\mathrm{t}}(233)=2.01, p=0.045$. For the Indecision subscale and RCI, no significant difference was found.

Table 4.17

T-Test scores for gender

\begin{tabular}{|c|c|c|c|}
\hline & & $d f$ & Sig.(2-tailed) \\
\hline CDS & -1.513 & 233 & .13 \\
\hline Certainty & 2.01 & 233 & .045 \\
\hline Indecision & -1.3 & 233 & .19 \\
\hline RCI & .43 & 232 & .668 \\
\hline
\end{tabular}

The mean scores for gender showed that males scored higher than females on the certainty subscale ( $\underline{\mathrm{M}}=3.2$ and $\underline{\mathrm{M}}=2.3$ respectively). There was no difference between males and females on the other scales.

Table 4.18

Mean scores for gender with CDS and RCI

\begin{tabular}{lccc}
\hline & Male & Female & Both \\
\hline CDS & 2.2 & 2.3 & 2.2 \\
& .55 & .57 & .57 \\
& 60 & 175 & 235 \\
Certainty & 3.2 & 2.9 & 3.0 \\
& .61 & .68 & .67 \\
Indecision & 2.1 & 2.3 & 2.2 \\
& .61 & .61 & .61 \\
RCI & 3.6 & 3.6 & 3.6 \\
& .55 & .72 & .68 \\
\hline
\end{tabular}

Relationship between Religious Commitment and Career Decision Making 
IIUM Journal of Educational Studies, 1:1 (2013) 98 - 149

Copyright (C) IIUM Press

The sixth hypothesis was that there is a positive correlation between confidence in career decisions and religious commitment. Bivariate correlations were conducted to test the hypothesis.

Table 4.19

Correlation coefficients of CDS and RCI

\begin{tabular}{lrrrr}
\hline & \multicolumn{1}{l}{ CDS } & Certainty & Indecision & RCI \\
\hline CDS & 1 & & & \\
Certainty & $-.408(* *)$ & 1 & & \\
Indecision & $.992(* *)$ & $-.289\left(^{* *}\right)$ & 1 & \\
RCI & .046 & $.225\left(^{* *}\right)$ & .079 & 1 \\
\hline
\end{tabular}

Note: CDS = Career Decision Scale; RCI= Religious Commitment Inventory ** Correlation is significant at the 0.01 level

Table 4.19 shows the relationships between the overall scores and subscales. The intercorrelations for the CDS subscales were highly significant at $p<.01$. The certainty subscales correlated negatively with indecision ( $r=-2.89)$. CDS correlated significantly at $p<.01$ with indecision at $(r=.992)$ and negatively with certainty subscale at $p<.01(r=-.408)$.

Results on correlations between CDS subscales and RCI showed a small yet significant relationship between CDS and RCI. The RCI correlates significantly $(p<.05)$ with CDS certainty subscale score $(r=.225)$. However, there was no significant relationship between RCI and CDS overall score and neither with CDS indecision subscale score.

\section{DISCUSSION AND CONCLUSION}


IIUM Journal of Educational Studies, 1:1 (2013) 98 - 149

Copyright (C) IIUM Press

The main hypotheses for the current study were: (a) the degree of religious commitment among students in IIUM is high, (b) the level of confidence in career decision making among IIUM students is high, and (c) there is a positive correlation between confidence in career decisions and religious commitment. The results of the study found that students in IIUM have high levels of religious commitment. Further analysis showed that the religious commitment is higher on personal beliefs and practices rather than contribution and participation in religious activities. The results showed no major difference between the specializations. The results also found that majority of students are comfortable with their career and major choice, but still lack knowledge about self and the world of work. Further analysis showed that males are more certain about their career choice compared to females, and International students are more decided in their career choice and major compared to local students. Results of correlation found that there is no statistically significant relationship between the overall CDS scores and RCI. However, there was a significant relationship between Certainty subscale and RCI.

The goal of the current study was to examine the relationship between religious commitment and career decision making among International Islamic University Malaysia students. In line with the first hypothesis, descriptive analysis showed that IIUM students have a high level of religious commitment. Thus, the first hypothesis is supported. This is consistent with the findings of Syed Sohail Imam (2009) who found that undergraduate students of International Islamic University Malaysia reported an adequate level of spiritual well-being including both religious and existential well-being. Subsequent analysis of frequency distributions of students in each specialization towards individual items on the scales indicated that there are 
IIUM Journal of Educational Studies, 1:1 (2013) 98 - 149

Copyright (C) IIUM Press

differences among the students' responses towards individual items where they scored higher on personal beliefs and lower on participation in religious activities. This is consistent with the findings of Rashid (2004) that Muslims had higher scores in religious behaviors, intrinsic orientation and extrinsic-personal orientation and lower scores in extrinsic-social orientation.

Another interesting finding was that students in IRKHS did not score much differently than students in other specializations, especially Economics students and Education students had scores higher. However, students in IRKHS are expected to have high religious commitment as they are in a religious field and take more religious subjects. A possible cause for this finding can be because the majority of respondents in IRKHS consist of students majoring in Human Science. And even though it is compulsory for them to take a minority in Islamic Revealed Knowledge, it is not necessary that they are inclined towards religious commitment.

The results also showed that IIUM students have a moderate confidence in career decision making. Thus, the second hypothesis is partially supported. Further analysis using crosstabulations showed that the majority of students are in need ofmore information about their careers and the world of work. This result is consistent with the findings of Gaffner and Hazler (2002) who found a correlation between the level of indecisiveness and the level of career readiness, the amount of occupational information received, and the amount of difficulty in decision-making. This finding supports trait and factor theory in which the theory proposes that for an individual to make a good career choice, it is essential that he or she must first understand himself or herself, then the world of work and then match both to find a good fit (Arthur, et al. 1993). Donald Super in his lifespan theory also suggests that 
IIUM Journal of Educational Studies, 1:1 (2013) 98 - 149

Copyright (C) IIUM Press

clients have a better chance of making optimal decisions when they are most aware of the working world and themselves. (Zunker, 2006).

In examining differences between international and local students on level of religious commitment, the results also showed that there is no significant difference between local students and international students with regards to religious commitment. This is contradictory to the findings of Houtouin (2005) who found that local students have high religiosity compared to international students who reported average on religiosity.

An analysis on gender differences indicated that there are significant differences between males and females on Career Decision Scale. It was found that male students scored higher on Certainty subscale than female students. These results are consistent with the findings of Zhou and Santos (2007). On the other hand, the results are contradictory to the results of Landry (2006) who found that females are more certain than males and had higher career satisfaction. The results showed no significant difference for gender on the Religious Commitment Inventory. This is consistent with the finding of Rashid (2004) in that males and females did not differ in their intrinsic or extrinsic religiosity. The current study also contradicts the results of Syed Sohail Imam (2009) in which the results showed that female students excelled their male counterparts significantly on the three measures of spiritual well being, religious well-being, and existential well-being.

Grade level differences were also found between students in terms of year in university. Students in third year reported more career indecision than students in fourth year. This supports the findings of Landry (2006) who found that seniors were more certain in their careers. However, no difference was found between students in other levels of study. This may indicate that students in their first two years at the 
IIUM Journal of Educational Studies, 1:1 (2013) 98 - 149

Copyright (C) IIUM Press

university do not think about their careers and only start to think when they are in the third year of their studies. In addition, when they reach fourth year, they are clearer about what they want in their career.

Finally, the results of the current study did not show any significant relationship between CDS and RCI as opposed to what was predicted in the hypothesis. This contradicts what researchers such as Royce-Davis and Stewart (2000) and Constantine, et al (2006) say. However, it is consistent with the findings of Duffy (2006a) who found that the correlations of God support and religious community support to career decision self efficacy were especially small. The results showed a significant, positive relationship between career certainty subscale and religious commitment. This may indicate that having a high level of religious commitment may increase students' certainty in their career decision, but not necessarily have any influence on their career indecision. This is likely because as the university is an Islamic university with its teachings based on Islam, the students are expected to have higher religious commitment. As such, it is not surprising that these students will also have a very high level of career decision making.

The discussion of limitation of study gives rise to suggestions for future research in the field. First of all, it is recommended that further exploration be completed to understand the role of religion in a person's career process. Though the current study explored religious commitment as a whole, a number of variables should be investigated, including intrinsic and extrinsic orientation. Similarly, future research can also investigate how religion may affect career decision self efficacy. 
IIUM Journal of Educational Studies, 1:1 (2013) 98 - 149

Copyright (C) IIUM Press

Additionally, studies can also be conducted with different age groups, and different religious backgrounds.

Research could also explore potential mediators and moderators, which connect religious commitment and career decision making. Furthermore, the outcome of the relationship can also be investigated by including a third variable such as academic performance or stress level. Finally, research could also be conducted to investigate how religion may relate to an individual's career interests, work values, and goals. 
IIUM Journal of Educational Studies, 1:1 (2013) 98 - 149

Copyright (C) IIUM Press

\section{BIBLIOGRAPHY}

Akcali, F. O. (2000). "An exploration of the relationship between spirituality and the career transition process in middle aged women's lives." Unpublished doctoral dissertation. McGill University.

Al Bukhari (Al Bukhari Correct Hadeeth Collection), Mohammad Bin Ismaeal Al Bukhari, Numbered by Mohammad Foad Abdulbaqi in his studies on "Fateh Al Barie Fe Sharh Sahih Al Bukhari” Ibn Hajar Al Asqalani, $2^{\text {nd }}$ Ed, Cairo, Dar Arrayan le Atturath, 1407 Hejra.

Amir, T. \& Gati, I. (2006). "Facets of career decision-making difficulties." British Journal of Guidance \& Counselling, 34(4), 483-503

Arthur, M. B. Hall, D. T. \& \& Lawrence, B.S. (1993). Handbook of career theory. England: Cambridge University Press.

Bigham, J. T. (2008). "Role of spirituality in persons choosing a career in education : Calling as a motivating factor." Unpublished doctoral dissertation. Liberty University.

Blando, J. A. (2006). "Spirituality, Religion and counseling." Counseling and Human Development. 39(2). 1-14.

Boyce, A. M. (2005). "An investigation of the role of religious support in reducing work-family conflict." Unpublished doctoral dissertation. Wayne State University.

Brown, D. R. (2008). "Assessment of spirituality in counseling: the relationship between spirituality and mental health." Unpublished doctoral dissertation. Auburn University.

Browne, L. A. (2001). "On faith and work: The relationship between religiosity and work values." Unpublished doctoral dissertation. University of Missouri.

Chandler, C. K. \& Holden, J. M. (1992). "Counseling for spiritual wellness: Theory and practice. "Journal of counseling development, 71, 168-176.

Cochran, L. (1991). Life-shaping decisions. New York: Lang.

Cohen, L. \& Manion, L. (1994). "Research methods in education $4^{\text {th }}$ ed." London : Routledge. 
IIUM Journal of Educational Studies, 1:1 (2013) 98 - 149

Copyright (C) IIUM Press

Collins, K. W. (2008). "Perceived career barriers, career outcome expectations, and spirituality among African American women and men." Unpublished doctoral dissertation. University of Memphis.

Colozzi, E., \& Colozzi, L. (2000). "College students' callings and careers: an integrated values-oriented perspective." In Career counseling of college students: an empirical guide to strategies that work, edited by Luzzo, D, 63-91.Washington, DC : American psychological Association.

Constantine, M. G., Miville, M. L., Warren, A. K., Gainor, K. A., \& Lewis-Coles, M. E. (2006). "Religion, Spirituality, and Career Development in African American College Students: A Qualitative Inquiry." Career Development Quarterly, 54(3), 227-241.

Corkin, D., Arbona, C., Coleman, N. \& Ramirez, R. (2008). "Dimensions of career indecision among Puerto Rican college students." Journal of college student Development. 49(2). 81-93.

Dalton, J. C. (2001). "Career and calling: Finding a place for the spirit in work and community." New directions for student services, 95, 17-25

Davidson, J.C., \& Caddell, D.P. (1994). "Religion and the meaning of work." Journal for the Scientific Study of Religion, 33,135-147.

Duffy, R. D. (2006a). "The relationship of god support and religious community support to career exploration and career decision self efficacy." Unpublished doctoral dissertation. University of Maryland.

Duffy, R. D. (2006b). "Spirituality, religion and career development: Current status and future direction." The Career Development Quarterly, 55(1), 52-63

Duffy, R. D., \& Blustein, D. L (2005). "The Relationship between Spirituality, Religiousness, and Career Adaptability." Journal of Vocational Behavior, 67(3), 429

Engels, D. W. (1994). The professional practice of career counseling and consultation: A resource document 2 nd ed. Alexandria, VA: American Counseling Association.

Etta, P. N. (1999) "Factors influencing career decision making among college seniors at selected urban universities." Unpublished doctoral dissertation. University of Texas.

Ferguson, P. A. (2007). "A relationship between career decision and motivation to persist. Unpublished doctoral dissertation." University of Central Florida. 
IIUM Journal of Educational Studies, 1:1 (2013) 98 - 149

Copyright (C) IIUM Press

Gaffner, D. C. \& Hazler, R. J. (2002). "Factors related to indecisiveness and career indecision in undecided college students." Journal of College Student Development. 43(3), 317-326.

Gati, I., Krausz, M., \& Osipow, S. H. (1996). "A taxonomy of difficulties in career decision making." Journal of Career Psychology, 43, 510-526.

Gay, L. R. (1993). Educational research: competencies for analysis and application ( $4^{\text {th }}$ ed.). New York: MacMillan Pub Co.

Gelso, C., \& Fretz, B. (2001). Counseling psychology. Belmont, CA: Wadsworth.

Giacalone, R. A. \& Jurkiewiez, C. I. (2003). Handbook of workplace spirituality and organizational performance. New York: M. E. Sharpe

Hansen, L. S. (2001). "Integrating Work, Family, and Community Through Holistic Life Planning." Career Development Quarterly , 49(3), 261-275

Heppner, M. J. \& Hendricks, F. (1995). "A process and outcome study examining career indecision and indecisiveness." Journal of Counseling and Development, 73, 426-437.

Hodge, D. R. (2005). "Social Work and the House of Islam: Orienting Practitioners to the Beliefs and Values of Muslims in the United States." Social Work. 50 (2), 162-174

Houtouin, Ramatou Mahamat (2005). "A study of social integration among students at IIUM." Unpublished MHsc Thesis. International Islamic University Malaysia.

Ibn Majah (Ibn Majah Hadeeth Collection), Abu Abdullah Mohammad Bin Yazeed Al Qazweeny, Bait Al Afkar Addowaleyah, Amman

Johnson, N. M. (2007). "The study and comparison of the level of motivation, attributional style, locus of control and career indecision between Black and White $9^{\text {th }}$ grade suburban students." Unpublished doctoral dissertation. Florida: University of Central Florida.

Ki-Hak Lee. (2005). "Coping with career indecision: Differences between four career choice types." Journal of career development. 31(4). 279-289.

Knox, D., Langehough, S. O., Walters, C. \& Rowley, M. (1998). "Religiosity and spirituality among college students." College Student Journal. 32(3). 1-3.

Korschegen, A. J. \& Hageseth, J. A. (1997). "Undecided students: How one college developed a collaborative approach to help students choose majors and careers." Journal of Career Planning \& Employment, 57(3), 49-51 
IIUM Journal of Educational Studies, 1:1 (2013) 98 - 149

Copyright (C) IIUM Press

Landry, J. C. (2006). "The relationship between career decision-making and level of anxiety among undergraduate students." Unpublished doctoral dissertation. Southern Illinois University Carbondale.

Leedy, P.D. \& Omrod, J. E. (2005). Practical research: Planning and design, $8^{\text {th }}$ ed. Canada: Pearson Education.

Lips-Wiersma, M. (2002). "The influence of spiritual "meaning making" on career behavior." Journal of Management Development, 21, 497-520.

Mahmoud Abdullah Saleh. (1987). "Counseling and guidance in the Kingdom of Saudi Arabia." International Journal for the Advancement of Counselling 10:277-286

McCullough, M.E., \& Larson, D.B. (1999). "Religion and depression: A review of the literature." Twin Research, 2,126-136.

McDaniels, C. \& Gysbers, N. C. (1992). Counseling for career development. California: Jossey-Bass Inc.

Mei, Tang., Wei Pang.,\& Newmeyer, M. D. (2008). "Factors influencing high school students' career aspirations." Professional School Counseling. 11, 285-295

Miller, W. R., \& Thoresen, C. E. (2003). "Spirituality, religion, and health: An emerging research field." American Psychologist, 58, 24-35.

Moshe, F. (2003). Career spirituality: Learning the R.O.P.E.S. U.S Department of Education.

Munqidh Ben Mahmoud Assaqar. (n.d). Become acquainted with Islam. Mecca: Muslim world league.

Nardi, P. M. (2003). Doing a survey research: a guide to quantitative methods. Boston: Allyn and Bacon.

Neck, C. P. \& Milliman, J. F. (1994). Thought self-leadership, finding spiritual fulfillment in organizational life. Journal of Managerial Psychology, 9(6), 916

Okubo, Y., Yeh, C. J., Lin, P. Y., Fujita, K. \& Shea, J. M. (2007). "The career decision-making process of Chinese American youth. "Journal of Counseling \& Development, 85, 440-429

Organization for economic co-operation and development. (2004). Career guidance and public policy: bridging the gap. Retrieved from: http://www.oecd.org/dataoecd/33/45/34050171.pdf

Osipow, S. H., Carney, C. G., Winer, J., Yanico, B., \& Koschier, M. (1987). The career decision scale. (3rd Ed). Odessa, FL: PAR, Inc. 
IIUM Journal of Educational Studies, 1:1 (2013) 98 - 149

Copyright (C) IIUM Press

Osipow, S. H. \& Winer, J. (1996). "Career Assessment and the career decision scale." Journal of Career Assessment, 4, 117-130.

Osipow, S. H. \& Fitzgerald, L. F. (1996). Theories of career development, $4^{\text {th }}$ ed. Boston: Allyn and Bacon.

Perrone, K. M., Webb, L. K., Wright, S. L, Jackson, Z. V. \& Ksiaza, T. M. (2006). "Relationship of spirituality to work and family roles and life satisfaction." Journal of Mental Health Counseling, 28(3), 253

Quek Ai Hwa. (n.d). Career guidance and counseling in Malaysia: development and trends. University of Malaya.

Ragab, I. A. (1980). Islam and development. Case Western Reserve University, Cleveland. Retrieved from: http://www.ibrahimragab.com/ebooks-16

Rashid M.A., (2004) "Religiosity and Psychological Well-being in a Malaysian Context." Malaysian Journal of Psychiatry, 12 (2). pp. 24-37. ISSN 0128-8628

Reardon, R. C., Lenz, J. G., Sampson, J. P. \& Peterson, G. W. (2000). Career development and planning: A comprehensive approach. Pacific Grove, CA: Brooks/Cole

Richmond, L. (2008). Role of Spirituality in Career Counseling With Women. American Psychological Association 2008 Convention Presentation. Loyola College In Maryland

Roberts, N. (2008). Spirituality and career decision making: facilitating student voices. American Psychological Association 2008 Convention Presentation: Brigham Young University

Royce-Davis, J., \& Stewart, M. (2000). Addressing the relationship between career development and spirituality when working with college students. Retrieved from ERIC database.

Salkind, H. J. (2009). Exploring research.7th Ed.Upper Saddle River, New Jersey. Pearson Education.

Savickas, M. L. (1995). "Constructivist counseling for career indecisions."Career Development Quarterly, 43, 363-373

Schafer, W. E. (1997). "Religiosity, spirituality, and personal distress among college students." Journal of College Student Development, 38(6) , 633-645

Seligman, L. (2004). Diagnosis and treatment planning in counselling. New York: Kluwer Academic/Plenum Publishers.

Sharf, R. S. (2004). Applying career development theory to counseling. Canada: Thomson Brooks/Cole. 
IIUM Journal of Educational Studies, 1:1 (2013) 98 - 149

Copyright (C) IIUM Press

Snorradottir, A. (2002)."Vocational identity formation and socioeconomic status among college freshmen." Unpublished M.sc thesis. California State University

Syed Sohail Imam .(2009)."Well-being of undergraduate university students." Paper presented at International Conference on Development and Ummatic Vision. July 28, 2009. International Islamic University Malaysia.

The Holy Quran.The Meaning of the Holy Quran, Abdullah Yusof Ali.

Thompson, K. D. (2001). "An exploratory study of factors influencing career certainty and indecision of high school students in the Bahamas." Unpublished doctoral dissertation. University of South Carolina

Trusty, Jerry, T. \& Watts, R. E. (1999). "Relationship of high school seniors' religious perceptions and behavior to educational, career, and leisure variables." Counseling \& Values, 44(1), 30.

Walker, K. L., \& Dixon, V. (2002). "Spirituality and academic performance among African American college students." Journal of Black Psychology, 28, 107-121.

Walsh, W. B. \& Osipow, S. H. (1988). Career Decision Making. New Jersey: Lawrence Erlbaum.

Worthington, E. L., Wade, N. G., Hight, T. L., Ripley, J. S., McCullogh, M. E., Berry, J. W., et al. (2003). "The religious commitment inventory-10: Development, refinement and validation of a brief scale for research and counseling." Journal of Counseling Psychology, 50(1), 84-96

Yousef, D. A. (2001). "Islamic work ethic: A moderator between organizational commitment and job satisfaction in a cross-cultural context." Personnel Review, 30(2), 152-169.

Zhou, D. \& Santos, A. (2007). "Career decision-making difficulties of British and Chinese international university students." British Journal of Guidance \& Counselling, 35(2), 219-235

Zunker, V. G. (1998). Career counseling: Applied concepts of life planning. New York: Brooks/Cole.

Zunker, V. G. (2006). Career counseling : A holistic approach, $7^{\text {th }}$ ed. Canada : Thomson Brooks/Cole. 